\title{
Identification of Cytauxzoon felis antigens via protein microarray and assessment of expression library immunization against cytauxzoonosis
}

\author{
Megan E. Schreeg ${ }^{1}$, Henry S. Marr ${ }^{1}$, Jaime L. Tarigo ${ }^{1,2}$, Meredith K. Sherrill ${ }^{3}$, Hilton K. Outi ${ }^{3}$, Elizabeth H. Scholl ${ }^{4}$, \\ David M. Bird ${ }^{4}$, Adam Vigil ${ }^{5}$, Chris Hung ${ }^{5}$, Rie Nakajima ${ }^{5}$, Li Liang ${ }^{5}$, Angela Trieu ${ }^{6}$, Denise L. Doolan, ${ }^{6,7}$, \\ Jennifer E. Thomas ${ }^{8}$, Michael G. Levy ${ }^{1}$, Mason V. Reichard ${ }^{8}$, Philip L. Felgner ${ }^{5}$, Leah A. Cohn ${ }^{3}$ \\ and Adam J. Birkenheuer ${ }^{1 *}$ (D)
}

\begin{abstract}
Background: Cytauxzoonosis is a disease of felids in North America caused by the tick-transmitted apicomplexan parasite Cytauxzoon felis. Cytauxzoonosis is particularly virulent for domestic cats, but no vaccine currently exists. The parasite cannot be cultivated in vitro, presenting a significant limitation for vaccine development.

Methods: Recent sequencing of the $C$. felis genome has identified over 4300 putative protein-encoding genes. From this pool we constructed a protein microarray containing 673 putative C. felis proteins. This microarray was probed with sera from C. felis-infected and naive cats to identify differentially reactive antigens which were incorporated into two expression library vaccines, one polyvalent and one monovalent. We assessed the efficacy of these vaccines to prevent of infection and/or disease in a tick-challenge model.
\end{abstract}

Results: Probing of the protein microarray resulted in identification of 30 differentially reactive $C$. felis antigens that were incorporated into the two expression library vaccines. However, expression library immunization failed to prevent infection or disease in cats challenged with C. felis.

Conclusions: Protein microarray facilitated high-throughput identification of novel antigens, substantially increasing the pool of characterized C. felis antigens. These antigens should be considered for development of C. felis vaccines, diagnostics, and therapeutics.

Keywords: Cytauxzoonosis, Cytauxzoon felis, Expression library immunization, Protein microarray, Piroplasmid, Vaccine

\section{Background}

Cytauxzoon felis is a tick-transmitted apicomplexan parasite that is the causative agent of cytauxzoonosis in domestic and wild felids in North and South America [1-8]. A closely related, genetically unique Cytauxzoon sp. has been identified in Europe [9-13], but has not

\footnotetext{
*Correspondence: ajbirken@ncsu.edu

${ }^{1}$ College of Veterinary Medicine, North Carolina State University, Research Building Room 464, 1060 William Moore Drive, Raleigh, NC 27607, USA
} Full list of author information is available at the end of the article been associated with classic cytauxzoonosis which is characterized by high mortality rates and massive proliferation and vascular dissemination of schizont-infected myeloid cells. Although no longer considered uniformly fatal in domestic cats, morbidity and mortality remain high for individuals presenting with acute cytauxzoonosis [14-19]. Even with treatment, which can cost thousands of dollars, mortality remains at least $40 \%$ [20]; a vaccine is not currently available. Following its initial discovery in Missouri in 1976, C. felis has since been 
detected in domestic cats in 19 states $[6,8,21,22]$ and in bobcats in two additional states [23, 24]. The prevalence of $C$. felis infections in enzootic regions of the USA has been reported at $6.2 \%$ [17], which is higher than the estimated prevalence rates of common infections like feline leukemia virus $(2.26 \%)$ and feline immunodeficiency virus (4.2\%, Companion Animal Parasite Council, https ://capcvet.org/maps/\#2017/all/felv/cat/united-states/, https://capcvet.org/maps/\#2017/all/fiv/cat/united-state $\mathrm{s} /$ ). This pattern could be due to a combination of factors, including an increase in feline reservoirs, expanding range of competent tick vectors (Amblyomma americanum and Dermacentor variabilis), and increased clinician awareness and diagnosis.

Prevention of cytauxzoonosis appears to be the optimal control strategy, and currently depends either on application of prophylactic acaricides [25], or keeping cats indoors. However, in practice, these strategies are flawed. Despite recommendations to house cats indoors, an estimated 35-60 million pet cats are still allowed to roam outdoors in the United States [26, 27]. Furthermore, effective acaricide prophylaxis may be limited by lack of owner compliance or cost of acaricides, as a recent study indicated as few as $38 \%$ of cats presenting to a veterinary teaching hospital had not received any form of tick prevention [28]. We therefore propose that vaccination against $C$. felis would serve as a practical and cost-effective method of prevention. Because cytauxzoonosis is highly pathogenic, a vaccine that reduces morbidity and mortality, even if it failed to prevent infection, would be considered successful.

There is some evidence that domestic cats can develop a protective immune response against $C$. felis. Previous studies have demonstrated that cats that survive acute cytauxzoonosis are protected from clinical disease following subsequent challenge with a lethal dose of virulent C. felis [4, 29-31]. However, antigen discovery and vaccine development have been hindered by the inability to cultivate $C$. felis in vitro. To redress this we previously sequenced and annotated the $C$. felis genome, and undertook a search for vaccine candidates [32] via an approach known as "reverse vaccinology" [33]. The underlying premise is that each of the 4300 putative proteins that were predicted [32] could represent a potential vaccine candidate. To date, a single $C$. felis vaccine candidate has been identified and characterized using a single candidate gene approach [32]. Although identification of candidates in such fashion is conceptually straightforward, this approach is both labor-intensive and cost-prohibitive when considering the number of inferred proteinencoding genes present in the $C$. felis genome. As a more efficient strategy, we deployed a protein microarray to screen a large number of $C$. felis proteins for antigenicity.
Protein microarray technology has been utilized as a strategy for identification and assessment of diagnostic and/or vaccine candidates for a variety of pathogens, including protozoal organisms [34-39] as well as fastidious organisms that have not been cultivated in vitro [40, 41]. Conceptually similar, an alternative, high throughput method for screening antigens as vaccine candidates in vivo is a DNA expression library immunization (ELI) approach. This entails immunization of individuals with a library of expression plasmids containing either a portion of or the entire genome of the infectious agent [42-44]. ELI has been used to identify protective antigens against a variety of protozoal infections in mice, including Plasmodium, Leishmania, and Trypanosoma species [42, 45-49].

Our goal was to develop a low-cost, fast-track approach for vaccine development that could be used for pathogens that are difficult to isolate/culture or for which there is limited funding available. The aims of this study were twofold. First, we described the utilization of a C. felis protein microarray for identification of antigens. Then we assessed the ability of these antigens to induce protection from clinical disease via ELI. Protein microarray successfully identified $30 \mathrm{C}$. felis antigens. However, ELI using these antigens failed to induce protection against disease or infection. Collectively, these data provide insight into the humoral immune response against $C$. felis, and help build a foundation for future vaccine development against $C$. felis.

\section{Methods \\ Cytauxzoon felis DNA isolation, RNA isolation and CDNA synthesis}

Cytauxzoon felis genomic DNA was extracted from leukoreduced blood (Purecell NEO Neonatal High Efficiency Leukocyte Reduction Filter for Red Cell Aliquots, PALL Corp., Port Washington, NY) using a commercially available kit (QIAamp DNA Blood Mini Kit Qiagen, Valencia, CA). RNA was extracted from liver tissue of a cat infected with $C$. felis using a commercially available kit (ZR Tissue and Insect RNA Kit, Zymo Research, Irvine, CA). Using this RNA as template, cDNA was synthesized with Taqman Reverse Transcription Reagents following the two step RTPCR protocol according to manufacturer's instructions (Roche, Mannheim, Germany).

Identification and selection of Cytauxzoon felis genes/ORFs Of the 4378 predicted C. felis proteins [32], we selected 864 as candidates (Additional file 1: Supplementary Data Set 1) to assess via protein microarray based on at least one of the following criteria: genomic synteny 
and/or sequence homology to antigenic proteins identified in related protozoal organisms; sequence homology to Plasmodium proteins that displayed heterologous reactivity against serum from cats infected with $C$. felis (data not shown); or the presence of putative features predicted in silico to increase antigenicity, including the presence of predicted signal peptides, transmembrane domains, and predicted antigenic sites (Signal P Server v.4.0 and TMHMM Server v.2.0 from the Center for Biological Sequence Analysis). Of the genes/ORFs encoding the 864 putative proteins, those that were 126-3804 bp in length were selected for amplification for inclusion on the protein microarray $(768 / 864)$.

\section{PCR amplification of linear acceptor vectors ( $p X T 7$ and PVAX1)}

We used high throughput homologous recombination to clone target genes for expression on the protein microarray (pXT7) and for incorporation into DNA vaccines (pVAX1). Linearized pXT7 was produced and amplified using previously described methods [50] with the following modification: Roche high-fidelity enzyme mix $(2.5 \mathrm{U})$ and a $1 \mathrm{X}$ concentration of Expand highfidelity buffer with $\mathrm{MgCl}_{2}$ was utilized (Roche, Mannheim, Germany).

Linearized pVAX1 (Invitrogen, Carlsbad, CA) was produced using identical methods as for pXT7. Primers were designed to amplify the linear acceptor vector and incorporate a Kozak sequence upstream of the cloning site and a stop codon downstream of the coding site (Additional file 2: Supplementary Table 1). The $25 \mu \mathrm{L}$ reaction consisted of $1 \mathrm{ng}$ of linearized pVAX1, 25 pmols of each primer (Forward: 5'-TAGATCCACTAGTCCAGTGTG3', Reverse: 5'-CCATGGTGGCCGAGCTCGGTACCA AGC-3'), 5 pmol of dNTPs, $1.155 \mathrm{U}$ of Expand high-fidelity enzyme mix, and a $1 \mathrm{X}$ concentration of Expand highfidelity buffer with $\mathrm{MgCl}_{2}$ (Roche, Mannheim, Germany). Thermal cycling conditions consisted of an initial denaturation step at $95{ }^{\circ} \mathrm{C}$ for $5 \mathrm{~min}$, followed by 35 amplification cycles $\left(94{ }^{\circ} \mathrm{C}\right.$ for $20 \mathrm{~s}, 50{ }^{\circ} \mathrm{C}$ for $30 \mathrm{~s}$, and $68{ }^{\circ} \mathrm{C}$ for $3.5 \mathrm{~min}$ ) and a final extension step at $72{ }^{\circ} \mathrm{C}$ for $5 \mathrm{~min}$ (Techne Inc., Burlington, NJ).

\section{PCR amplification of Cytauxzoon felis genes/ORFs for protein microarray and DNA vaccine}

For genes/ORFs included on protein microarray, we designed primers that included cassettes homologous cloning sites of the linearized pXT7 (Forward cassette: 5'-ACGACAAGCATATGCTCGAG-3', Reverse cassette: $5^{\prime}$-TCCGGAACATCGTATGGGTA-3'); ORFs that were larger than 3000 bp were split into smaller fragments as needed for efficient amplification. Each $50 \mu \mathrm{L}$ reaction contained $1 \mu \mathrm{L}$ of genomic C. felis DNA template or cDNA, 50 pmol of each primer, $10 \mathrm{nmol}$ of deoxynucleoside triphosphates (dNTPs), $2.5 \mathrm{U}$ of Expand highfidelity enzyme mix, and a $1 \mathrm{X}$ concentration of Expand high-fidelity buffer with $\mathrm{MgCl}_{2}$ (Roche, Mannheim, Germany). Thermal cycling conditions consisted of an initial denaturation step at $95^{\circ} \mathrm{C}$ for $5 \mathrm{~min}$, followed by $40-45$ amplification cycles $\left(95^{\circ} \mathrm{C}\right.$ for $30 \mathrm{~s}, 55^{\circ} \mathrm{C}$ for $15 \mathrm{~s}, 50{ }^{\circ} \mathrm{C}$ for $15 \mathrm{~s}$, and $68^{\circ} \mathrm{C}$ for $3 \mathrm{~min}$ ) and a final extension step at $68^{\circ} \mathrm{C}$ for $10 \mathrm{~min}$ (Techne Inc., Burlington, NJ).

Similarly, for candidates included in the DNA vaccine, we designed primers with cassettes homologous to cloning sites of pVAX1 (Forward cassette: $5^{\prime}$-ACCGAGCTC GGCCACCATGG-3', Reverse cassette: 5'-CACACT GGACTAGTGGATCTA-3'). Each $25 \mu \mathrm{L}$ reaction contained $1 \mu \mathrm{L}$ of genomic $C$. felis DNA template or cDNA (Additional file 2: Supplementary Table 1), $25 \mathrm{pmol}$ of each primer, $5 \mathrm{nmol}$ of dNTPs, $1.75 \mathrm{U}$ of Expand highfidelity enzyme mix, and a 1X concentration of Expand high-fidelity buffer with $\mathrm{MgCl}_{2}$ (Roche, Mannheim, Germany). Thermal cycling conditions consisted of an initial denaturation step at $94{ }^{\circ} \mathrm{C}$ for $5 \mathrm{~min}$, followed by 40 amplification cycles $\left(94{ }^{\circ} \mathrm{C}\right.$ for $30 \mathrm{~s}, 55^{\circ} \mathrm{C}$ for $15 \mathrm{~s}, 50{ }^{\circ} \mathrm{C}$ for $15 \mathrm{~s}$, and $68{ }^{\circ} \mathrm{C}$ for $4 \mathrm{~min}$ ) and a final extension step at $68^{\circ} \mathrm{C}$ for 7 min (Techne Inc., Burlington, NJ).

PCR conditions were optimized for individual genes/ ORFs as needed, and amplicons were confirmed by gel electrophoresis for correct size prior to proceeding to homologous recombination.

\section{High throughput homologous recombination cloning}

All successfully amplified genes/ORFs were cloned into the appropriate plasmid expression vector (pXT7 for the microarray or pVAX1 for DNA vaccine) using a high throughput PCR recombination cloning method as previously described [50]. While the majority of plasmids cloned with pXT7 for the protein microarray were isolated without colony selection as described [50], colony selection was utilized for those plasmids cloned with pVAX1 for the DNA vaccine. Minipreps of clones were confirmed to have the correct insert via PCR using ORF sequence-specific primers and/or bi-directionally sequencing using T7 and BGH reverse primers; internal sequencing primers were designed and utilized as needed to obtain complete bi-directional sequencing (MCLAB, South San Francisco, CA).

\section{Protein microarray printing}

The expression of successfully cloned genes/ORFs was carried out for $5 \mathrm{~h}$ via in vitro transcription-translation (IVTT) according to manufacturer's directions (RTS $E$. 
coli HY 100 kit, biotechrabbit GmbH, Germany) with addition of $0.067 \mathrm{mM}$ Brij-98. A selection of ORFs that were predicted to be soluble $(n=137)$ were expressed in duplicate and transferred to plates without addition of Brij-98. Crude proteins were printed immediately without purification on nitrocellulose-coated glass NOVA slides (Grace Bio Labs, Bend, Oregon 97702) using an OmniGrid 100 microarray printer (GeneMachines, San Carlos, CA). Controls spotted onto chips included IVTT reactions without plasmid and purified IgG, and protein expression was confirmed by probing for polyhistidine (clone His-1, Sigma) and hemagglutinin tags (clone 3F10, Roche) included within the PXT7 vector.

\section{Protein microarray probing}

Serum was collected from 48 cats throughout the United States (20 cats PCR positive for $C$. felis, 20 cats PCR negative for $C$. felis, and 8 SPF cats that were PCR negative for C. felis). All 20 infected cats were known to have survived acute cytauxzoonosis. Four of these $C$. felis infected cats were known to be acutely infected and 4 were chronically infected.

Sera were diluted to 1:200 in Protein Array Blocking Buffer (GVS, Sanford, ME) with $10 \%$ (vol/vol) E. coli lysate and incubated at room temperature for $30 \mathrm{~min}$. Blocking anti-E. coli antibodies in the serum samples with $E$. coli lysate helps reducing background reactivity against $E$. coli proteins from IVTT reactions. Arrays were rehydrated in Protein Array Blocking Buffer and incubated in sera overnight at $4{ }^{\circ} \mathrm{C}$ with constant agitation. Slides were then rinsed $10 \mathrm{mM}$ Tris buffer (TBS, pH 8.0) containing $0.05 \%$ Tween-20 (TTBS), then incubated in biotin-conjugated, goat anti-cat immunoglobulin (antiIgGfcc, Jackson Immuno Research, West Grove, PA) diluted 1/200 in blocking buffer. After rinsing the slides, bound antibodies were detected by incubation with streptavidin conjugated SureLightH P-3 (Columbia Biosciences, Frederick, MD). The slides were then washed three times in TTBS and three times in TBS followed by a final water wash. The slides were air dried after brief centrifugation and analyzed using a Perkin Elmer ScanArray Express HT microarray scanner (Waltham, MA).

\section{Protein microarray statistical analysis}

The protein microarrays used here do not meet the criteria for required deposition under MIAME guidelines [51], and alternatives to standardize protein microarray results are in development to insure that all information can be easily interpreted (description of minimum information about a proteomics experiment [MIAPE] can be found here [52]). Intensities were quantified using
QuantArray software utilizing automatic local background subtraction for each spot. "No DNA" controls consisting of $E$. coli IVTT reactions without addition of plasmid were averaged and used to subtract background E. coli reactivity from the unmanipulated raw data. All results presented are expressed as signal intensity. As previously reported [53], the "vsn" package in the Bioconductor suite (http://Bioconductor.org/) in the R statistical environment (http://www.R-project.org) was used to calculate seroreactivity. In addition to the variance correction, this method calculates maximum likelihood shifting and scaling calibration parameters for different arrays, using known non-differentially expressed spots. This calibration has been shown to minimize experimental effects [54]. We used raw values for the positive and negative controls to calibrate, and then normalize, the entire data set using the vsn package. Antigens were considered to be reactive if signal intensities were greater than the average signal intensity of the "No DNA" control spots, plus 1.5-times the standard deviation. Differential analysis of the normalized signals was then performed using a Bayes-regularized $t$ test adapted from Cyber-T for protein arrays [55-58]. Benjamini-Hochberg $p$ value adjustments were applied to account for multiple test conditions [59]. All p values shown are Benjamini-Hochberg corrected for false discovery.

\section{In silico analysis of antigens selected for inclusion in vaccines}

A total of 33 different $C$. felis antigens printed on the protein microarray were chosen for inclusion two DNA vaccines (Table 1). Each candidate was assessed for amino acid sequence similarity to other Piroplasmida proteins via BLAST search (blastx) against Theileria and Babesia species genomes (PiroplasmaDB, http://piroplasma db.org/piro/), Plasmodium species genomes (PlasmoDB, http://plasmodb.org/plasmo/), or all banked nucleotide sequences in the National Center for Biotechnology Information (NCBI, https://blast.ncbi.nlm.nih.gov/Blast .cgi).

\section{Production of vaccines}

Individual colonies confirmed to contain plasmids of interest were selected and grown in $150 \mathrm{~mL} \mathrm{LB} /$ kanamycin $(50 \mu \mathrm{g} / \mathrm{mL})$ and were isolated according to manufacturer's instructions (Zyppy Plasmid Maxiprep Kit, Zymo Research, Irvine, CA) or were commercially prepared (Genewiz, South Plainfield, NJ). Multiple maxipreparations were performed as needed to attain the desired final amount of plasmid. Plasmids were further concentrated by ethanol precipitation as necessary and were 


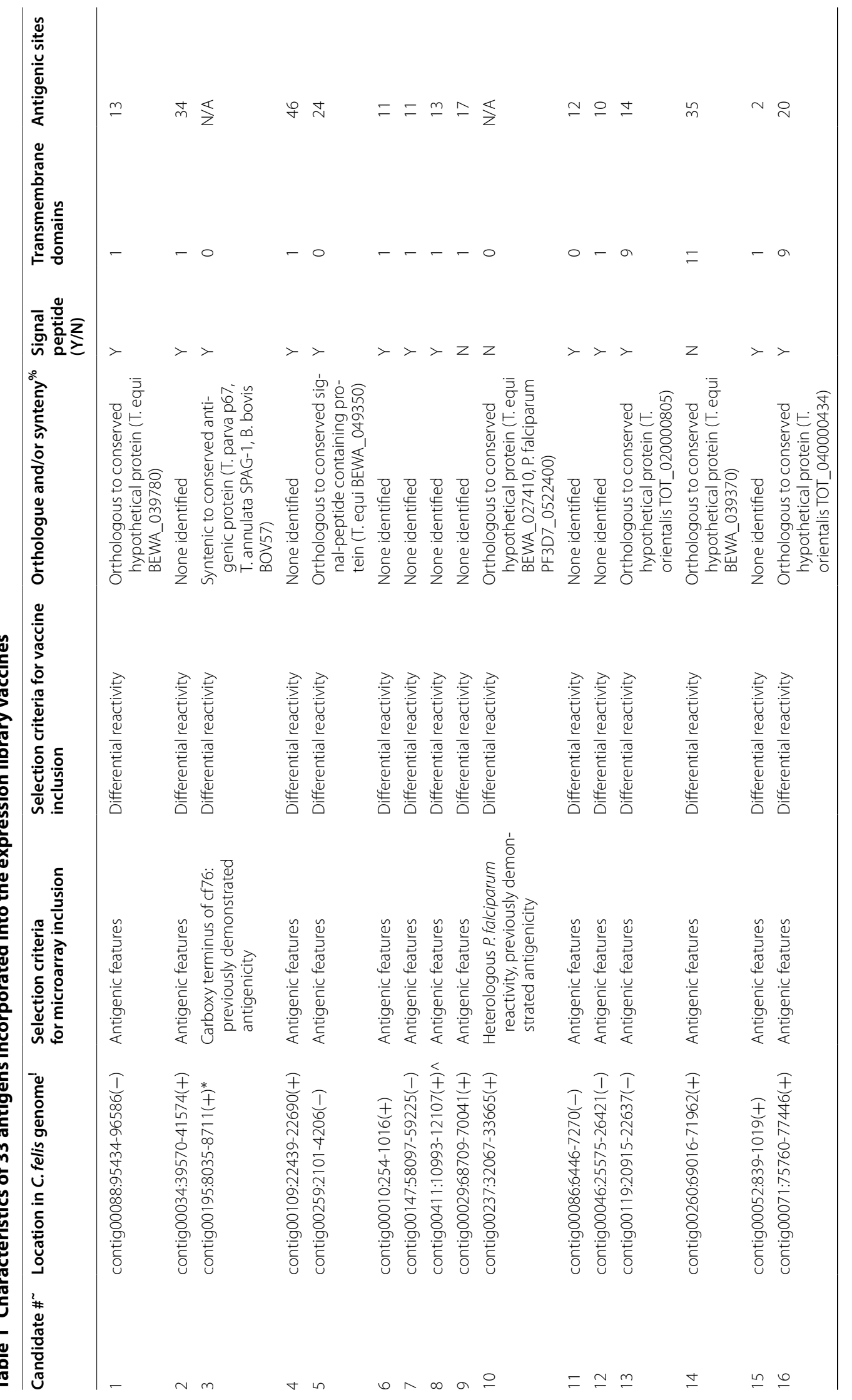


Schreeg et al. Clin Proteom ～(2018) 15:44

Page 6 of 17

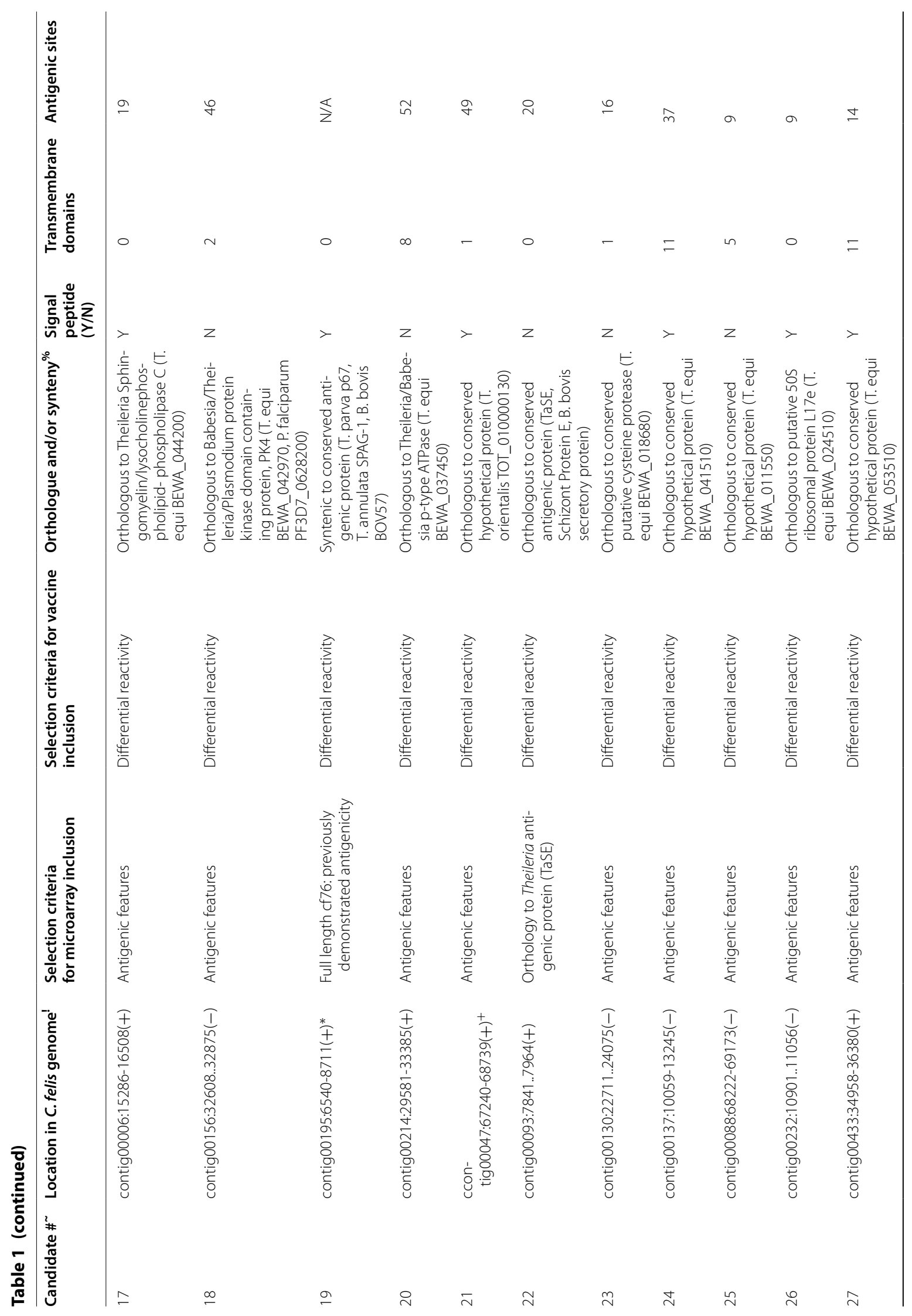


Schreeg et al. Clin Proteom ～(2018) 15:44

Page 7 of 17

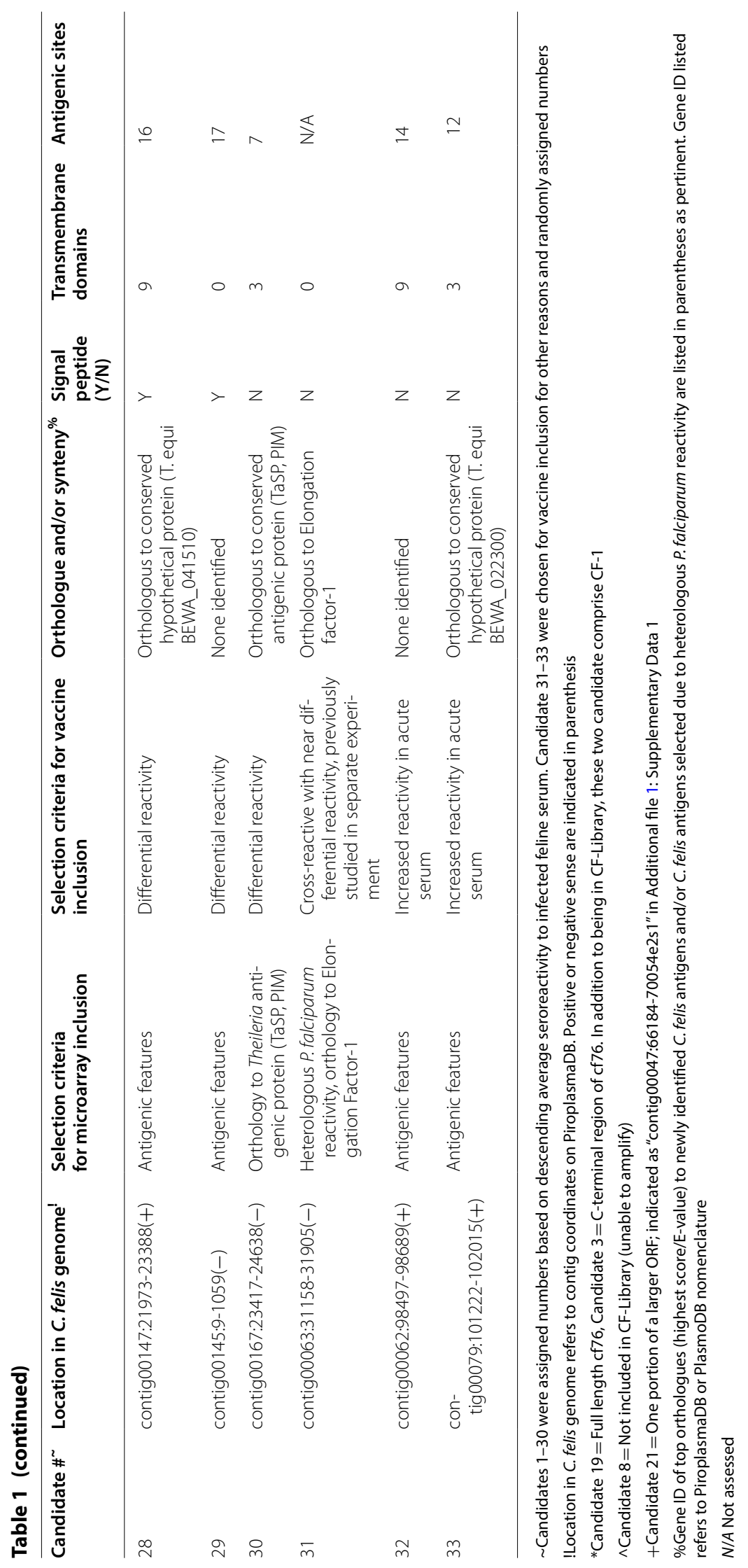


resuspended in endotoxin-free tissue culture grade distilled water (Thermo Fisher Scientific, Waltham, MA).

Two different vaccines were developed: "CF-Library" and "CF-1." CF-Library consisted of 32 candidates, while CF-1 consisted of both the carboxy-terminal region and full-length C. felis cf76 (Additional file 2: Supplementary Table 1) [32]. Each vaccine dosage contained a total of $1 \mathrm{mg}$ of DNA. CF-1 contained $500 \mu \mathrm{g}$ each of C-terminal region cf76 and full-length cf76, while CF-Library contained $31.25 \mu \mathrm{g}$ of each of the 32 plasmids.

\section{Animals}

Eighteen, 11-18 month old, intact female purpose bred cats that were PCR negative for $C$. felis were obtained from a commercial supplier (Liberty Research, Inc., USA). Cats were cared for according to the principles outlined in the National Institutes of Health Guide for the Care Use of Laboratory Animals and were housed in AAALAC accredited facilities within sealed, climatecontrolled isolation rooms with $12 \mathrm{~h}$ light/dark cycles. All animal use was approved by the University of Missouri Animal Use and Care Committee (protocol number 7909).

\section{Vaccine study design}

Cats were randomly assigned to test and control groups, which are summarized in Additional file 3: Supplementary Fig. 1. Seven cats received vaccines: three cats (331, 623 , and 638) received CF- 1 and four cats $(77,308,339$, and 835 ) received CF-Library. Investigators were blinded to whether vaccinated cats received CF-Library or CF-1. Eleven cats did not receive vaccines: eight of these were infected with C. felis (positive controls for infection) and three were infested with C. felis-naive ticks (negative controls for infection). Unvaccinated cats were also simultaneously enrolled in separate studies testing the efficacy of novel chemotherapeutics against cytauxzoonosis and the immune response to tick infestation and/or C. felis infection.

The schedule of vaccination and infection is summarized in Additional file 4: Supplementary Fig. 2. Cats within both vaccine test groups received three intramuscular (IM) injections. For the first two vaccinations (Day 6 and Day 30), cats received $1 \mathrm{mg}$ of DNA $(0.7 \mathrm{~mL}$ volume) via needle and syringe in the left (Day 6) or right (Day 30) cranial thigh (quadriceps femoris muscle). The third and final vaccination (1 mg of DNA in $0.25 \mathrm{~mL}$ ) was administered on Day 50 in the caudal medial right thigh via VET JET transdermal vaccination system (Merial, Inc., Athens, Georgia). When using the VET JET device, cats were sedated with dexdomitor $(15-20 \mathrm{ug} / \mathrm{kg})$ and acepromazine $(0.1 \mathrm{mg} / \mathrm{kg})$ delivered intravascularly (IV).

\section{Challenge model}

Cats were infected with C. felis 59 days after initial vaccination (Additional file 4: Supplementary Fig. 2) using tick transmission as previously described [25]. Uninfected cats were identically infested with C. felis-naïve ticks. For tick infestation, cats were anesthetized as described for transdermal vaccination above. Ticks were removed from cats 10-13 days post infestation, and the number of free and attached ticks as well as subjective engorgement of ticks were recorded for each cat (Additional file 5: Supplementary Table 2).

\section{Clinical evaluation}

Once infected cats were inspected at least four times a day. Physical exams were performed daily, and attitude, heart rate, respiratory rate, and body temperature (measured rectally or by subcutaneous temperature chip (IPTT-3000, Bio Medic Data Systems, Seaford, DE)) were recorded 2-4 times daily.

Starting at 12 days post-infection and finishing at the resolution of clinical symptoms or death, blood was collected from each cat via the jugular vein or a subcutaneous venous access port (VAP; CompanionPort CP4, Access Technologies, Skokie, IL). Blood was collected into EDTA for complete blood count (CBC; Sysmex XT2000i V Automated Hematology Analyzer) and into red top tubes for serum biochemical profile (Olympus 400AUe Chemistry Analyzer). Frequency of hematologic and biochemical testing performed for each individual cat was dictated by severity of illness and discretion of attending veterinarian but was generally performed every-other-day, and peaks and/or nadirs of clinicopathologic parameters were compared.

\section{Therapeutic intervention}

Supportive care and/or antiprotozoal therapy was initiated on a case by case basis at the discretion of attending veterinarian based on assigned treatment group (unvaccinated infected cats) or at the discretion of attending veterinarian if treatment was unassigned (vaccinated cats). Specific supportive therapies administered varied between cats and were tailored to the clinical needs of the individual (Additional file 6: Supplementary Table 3). Three different antiprotozoal treatment regimens were utilized in this study: two were experimental therapies that were administered to unvaccinated infected cats as a part of a separate study (Additional file 3: Supplementary Fig. 1). Experimental therapies included either Coartem $[20 \mathrm{mg}$ artemether $+120 \mathrm{mg}$ lumefantrine/tablet (Novartis), 2 tablets BID for 3 days] or a combination of 4 oral antibiotics, referred to through the study as " $4 \mathrm{X}$ Abx" (pradofloxacin $7.5 \mathrm{mg} / \mathrm{kg}$ q24 h, doxycycline $10 \mathrm{mg} /$ 
$\mathrm{kg} \mathrm{q12} \mathrm{h,} \mathrm{metronidazole} 25 \mathrm{mg} / \mathrm{kg} \mathrm{q} 12 \mathrm{~h}$, clindamycin $10 \mathrm{mg} / \mathrm{kg}$ q12 h until clinical improvement). For any cat that developed advanced cytauxzoonosis despite vaccination or experimental treatments, atovaquone (Mepron, GlaxoSmithKline) and azithromycin was administered as previous described [20].

\section{Assessment of infection, disease, and survival}

Infection was confirmed by PCR amplification of parasite DNA (ITS-1 and/or 18S) as previously described [60-62] and if possible by identification of parasites via microscopic evaluation of blood smears. Cytauxzoonosis was defined as cats being febrile (body temperature $\geq 102.5^{\circ} \mathrm{F}$ ) and having at least one of the following three biochemical/hematological abnormalities: hyperbilirubinemia $(>0.3 \mathrm{mg} / \mathrm{dL})$, neutropenia $\left(<2.5 \times 10^{3}\right.$ segmented neutrophils $/ \mu \mathrm{L})$, or thrombocytopenia $\left(<300 \times 10^{3}\right.$ platelets $\left./ \mu \mathrm{L}\right)$. Survival rates of groups were compared using the Freeman Halton extension [63] of the Fisher exact probability test with significance set at $\mathrm{p} \leq 0.05$ (VassarStats, Poughkeepsie, NY).

\section{Assessment of humoral responses post vaccination and challenge}

After the completion of the clinical trial portion of the vaccine pilot study, $C$. felis protein microarrays were probed as described above with sera obtained from cats from each test group. Sera were collected from vaccinated cats at 5-7 different time points throughout the study and were frozen at $-80^{\circ} \mathrm{C}$ until protein microarray analysis (Additional file 4: Supplementary Fig. 2).

\section{Results}

\section{Construction and quality assessment of Cytauxzoon felis} protein microarray

Of the $864 \mathrm{C}$. felis genes/ORFs initially selected for analysis, 96 ORFs were excluded from further study due to small size and predicted minimal antigenicity and 48 ORFs were unable to be PCR amplified, leaving 720 genes/ORFs amplified for cloning. Of these, 15 were unable to be cloned, and 32 had an incorrectly-sized insert in the pXT7 plasmid, leaving a total of 673 proteins for printing on the protein microarray $(93.5 \%$ cloning efficiency). Of these proteins, 633 proteins (94.07\%) were efficiently expressed as determined by dual positive signals against the amino-terminal HIS and carboxy-terminal hemagglutinin (HA) tags.

\section{Identification of $C$. felis antigens and selection of vaccine candidates}

The antibody response profile to $C$. felis proteins in infected, uninfected, and SPF domestic cats is shown as a heatmap in Fig. 1. Of the total 673 genes/ORFs probed, a total of 38 (5.6\%) were found to be seroreactive to feline serum. Of these, 30 were differentially reactive to serum from $C$. felis infected cats $(\mathrm{p}<0.05)$ and 8 were crossreactive to both infected and uninfected feline serum ( $p>0.05)$. The number of infected and uninfected cats reacting to differentially reactive and cross-reactive proteins is summarized in Table 2.

Protein features of the 30 differentially reactive proteins include 21 proteins with a predicted signal peptide and 21 proteins with at least one and up to 11 predicted transmembrane domains (Table 1 ). All 30 proteins were predicted to have at least two and up to 52 antigenic sites (Table 1). Of these 30 proteins, four had been selected for placement on the microarray due to known orthology with antigenic proteins from related organisms (Table 1). One protein was selected due to homology to a conserved Plasmodium protein that previously showed reactivity against serum from $C$. felis infected cats (data not shown, Table 1 ). The remaining 25 proteins were selected for placement on the protein microarray primarily due to in silico predicted antigenicity, but on further investigation at least 15 of these proteins showed some degree of orthology to proteins from related organisms (Table 1). Ultimately, all 30 of the differentially reactive proteins were selected for incorporation into CF-Library (Table 1).

One cross-reactive protein was also selected for inclusion into CF-Library (Elongation Factor-1 orthologue). This protein was nearly classified as being differentially reactive ( $p=0.052$, Fig. 1$)$, and was differentially reactive on a heterologous microarray screening sera from $C$. felis infected cats against Plasmodium falciparum antigens (Candidate 31, Table 1).

Of the infected feline serum samples, four were known to be collected while the cat was suffering from acute cytauxzoonosis, while four were known to be collected $>1$ year after resolution of disease but while the cat remained persistently parasitemic. The antibody response profile to $C$. felis proteins in these samples were compared to assess for kinetic changes in serologic profile against C. felis (Additional file 7: Supplementary Fig. 3). A total of 52 proteins were found to be reactive (signal intensity $>1.5 \mathrm{X}$ No DNA standard deviation) to sera from either acute or chronically infected cats. No significant difference was seen $(\mathrm{p}>0.05)$ for any proteins when comparing reactivity between serum of chronically or acutely infected cats. The majority of the proteins $(n=50)$ had a higher average reactivity against sera from chronically infected cats. However, two proteins had a higher average reactivity against sera from acutely infected cats (Additional file 7: Supplementary Fig. 3). These two proteins were also selected for inclusion in CF-Library (Candidates 32-33, Table 1). 


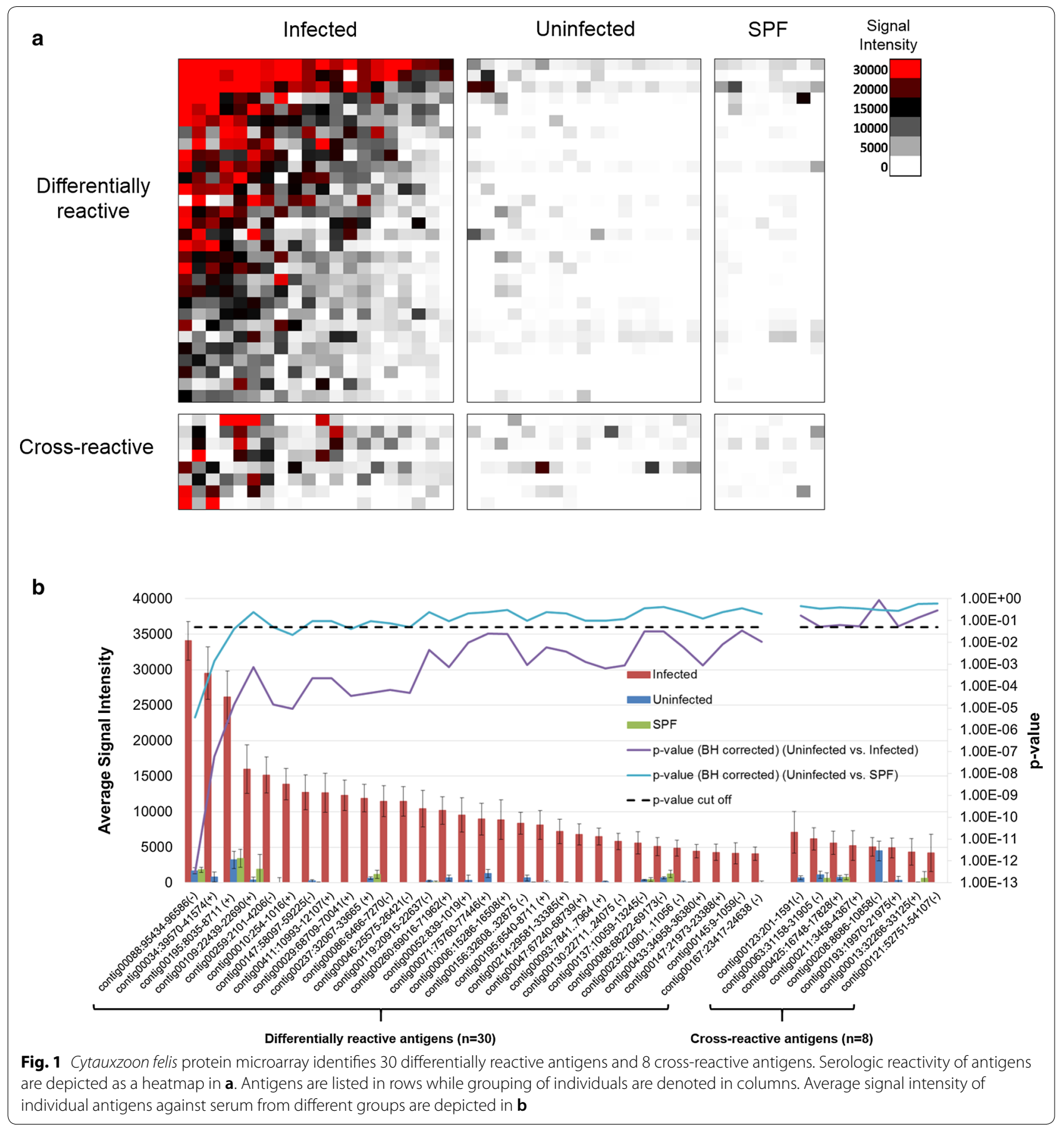

\section{Vaccination and challenge}

Of the 33 C. felis genes/ORFs selected for ELI, 32 were successfully cloned into the expression plasmid pVAX1 (97\% cloning success rate; Table 1). Both developed vaccines (CF-Library and CF-1) were delivered successfully to cats (no significant volume loss during administration), with no adverse clinical effects observed post-vaccination (Additional file 4: Supplementary Fig. 2).
All cats infested with $C$. felis positive ticks met the criteria for both infection and cytauxzoonosis (Table 3), with the majority ( $n=13 / 15$ infected cats) exhibiting at least two of the three biochemical/hematological abnormalities that were considered disease-defining. No parasites were detected for cats infested with $C$. felis-naïve ticks and those cats did not develop cytauxzoonosis. 
Table 2 Summary of the number of cats with reactivity to differentially and cross reactive antigens

\begin{tabular}{|c|c|c|c|}
\hline Order of reactivity & Location in C. felis genome & $\begin{array}{l}\text { Number of infected cats } \\
\text { with + reaction }\end{array}$ & $\begin{array}{l}\text { Number of uninfected } \\
\text { cats with + reaction }\end{array}$ \\
\hline \multicolumn{4}{|l|}{ Differentially reactive } \\
\hline 1 & contig00088:95434-96586(-) & 20 & 2 \\
\hline 2 & contig00034:39570-41574(+) & 19 & 1 \\
\hline 3 & contig00195:8035-8711(+) & 20 & 3 \\
\hline 4 & contig00109:22439-22690(+) & 16 & 1 \\
\hline 5 & contig00259:2101-4206(-) & 17 & 0 \\
\hline 6 & contig00010:254-1016(+) & 18 & 0 \\
\hline 7 & contig00147:58097-59225(-) & 16 & 0 \\
\hline 8 & contig00411:10993-12107(+) & 14 & 0 \\
\hline 9 & contig00029:68709-70041(+) & 14 & 0 \\
\hline 10 & contig00237:32067-33665(+) & 16 & 0 \\
\hline 11 & contig00086:6446-7270(-) & 15 & 0 \\
\hline 12 & contig00046:25575-26421(-) & 15 & 0 \\
\hline 13 & contig00119:20915-22637(-) & 11 & 0 \\
\hline 14 & contig00260:69016-71962(+) & 14 & 2 \\
\hline 15 & contig00052:839-1019(+) & 10 & 1 \\
\hline 16 & contig00071:75760-77446(+) & 11 & 3 \\
\hline 17 & contig00006:15286-16508(+) & 10 & 1 \\
\hline 18 & contig00156:32608..32875(-) & 14 & 1 \\
\hline 19 & contig00195:6540-8711(+) & 11 & 0 \\
\hline 20 & contig00214:29581-33385(+) & 10 & 0 \\
\hline 21 & contig00047:67240-68739(+) & 11 & 0 \\
\hline 22 & contig00093:7841..7964(+) & 11 & 0 \\
\hline 23 & contig00130:22711..24075(-) & 12 & 0 \\
\hline 24 & contig00137:10059-13245(-) & 6 & 0 \\
\hline 25 & contig00088:68222-69173(-) & 7 & 0 \\
\hline 26 & contig00232:10901..11056(-) & 8 & 0 \\
\hline 27 & contig00433:34958-36380(+) & 10 & 0 \\
\hline 28 & contig00147:21973-23388(+) & 9 & 0 \\
\hline 29 & contig00145:9-1059(-) & 7 & 0 \\
\hline 30 & contig00167:23417-24638(-) & 8 & 0 \\
\hline \multicolumn{4}{|l|}{ Cross reactive } \\
\hline 1 & contig00123:201-1591(-) & 5 & 1 \\
\hline 2 & contig00063:31158-31905(-) & 10 & 1 \\
\hline 3 & contig00425:16748-17828(+) & 6 & 1 \\
\hline 4 & contig00211:3458-4367(+) & 6 & 0 \\
\hline 5 & contig00208:8686-10858(-) & 7 & 7 \\
\hline 6 & contig00193:19970-21975(+) & 8 & 1 \\
\hline 7 & contig00013:32266-33125(+) & 5 & 0 \\
\hline 8 & contig00121:52751-54107(-) & 3 & 0 \\
\hline
\end{tabular}

Antigens are listed in order of descending average seroreactivity against C. felis-infected serum

With the exception of one cat vaccinated with CFLibrary, all infected cats received supportive care and antiprotozoal therapy (Table 3, Additional file 6: Supplementary Table 3 ). None of the uninfected cats became ill or required treatment (Table 3 ).
Survival of individual cats is summarized in Fig. 2 and Table 3. Survival rate of the infected cats vaccinated against CF-Library was $100 \%$ (4 out of 4 cats survived). Survival rate of the infected cats vaccinated against CF-1 was 33\% (1 out of 3 cats survived). Survival rate of the unvaccinated infected cats was $75 \%$ (6 out of 8 cats 


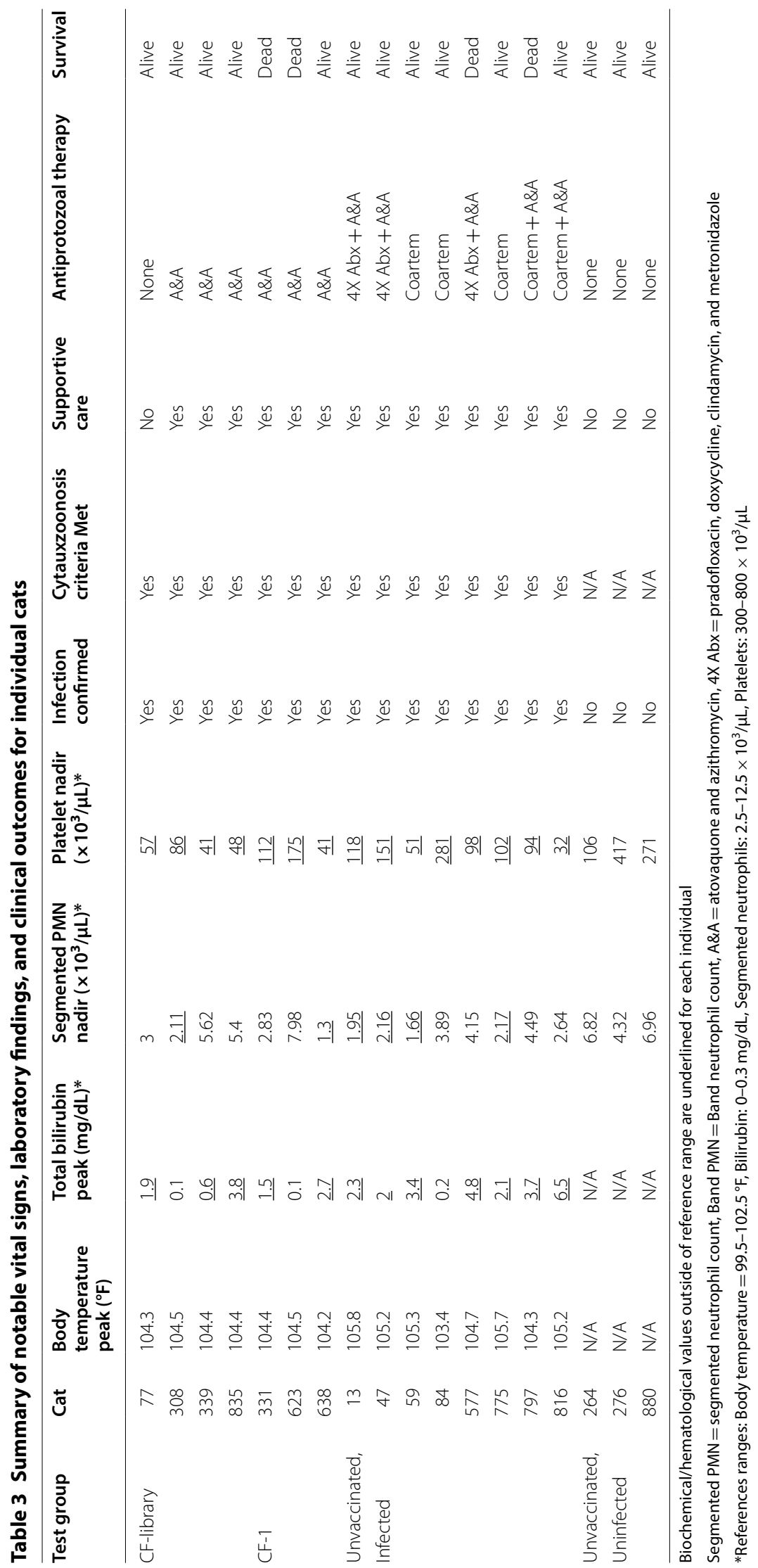




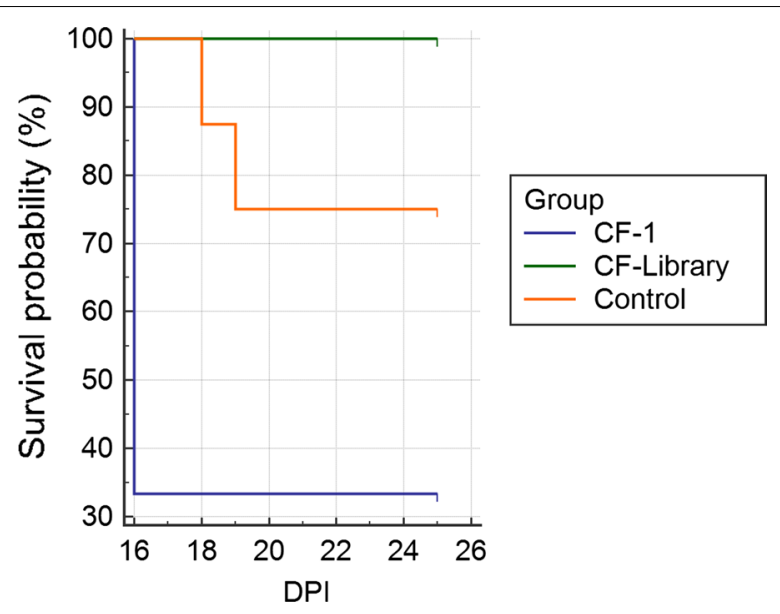

Fig. 2 Cats vaccinated with CF-Library have a higher survival rate (100\%) than other infected cats. Cats vaccinated with CF-1 had a $33 \%$ survival rate and unvaccinated, infected cats had a survival rate of $75 \%$. Unvaccinated, uninfected cats also had a $100 \%$ survival rate (data not shown). DPI days post infection

survived). Survival rate of uninfected cats was $100 \%$ (3 out of 3 cats survived). However, there was no significant difference between survival rates of groups $(\mathrm{p}>0.05)$.

\section{Retrospective serological profiles of individual cats in response to vaccination and challenge}

The serological responses of individual cats to vaccination varied (Additional file 8: Supplementary Fig. 4). Five cats (all cats vaccinated with CF-Library, one cat vaccinated with CF-1) developed a positive response to at least one antigen that they were vaccinated against prior to infection with $C$. felis (Table 4, Additional file 8: Supplementary Fig. 4). Two cats (two cats vaccinated with CF-1) failed to develop a positive response to any antigens vaccinated against prior to infection with $C$. felis, and in fact, these two cats only developed positive responses to antigens that they were not vaccinated against, including Candidates 4, 15, and 31 (Table 4, Additional file 8: Supplementary Fig. 4).

Additionally, all seven vaccinated cats developed a positive response to Candidate 31 (Elongation factor-1) regardless of what they were vaccinated against, making it unclear whether the increase in seroreactivity against this candidate was C. felis-specific or not. When disregarding the positive responses against Candidate 31, only two cats developed positive responses against any other antigens they were vaccinated against. These included a positive response against either partial length cf76 (Cat 623, CF-1) or both partial and full length cf76 (Cat 77, CF-Library).

\section{Discussion}

This study describes the construction and probing of a Cytauxzoon felis protein microarray for identification of antigenic proteins, the subsequent incorporation of those antigens into two expression library vaccines, and the evaluation of those vaccines to prevent clinical disease in cats challenged with $C$. felis infection. Using these methods, we were able to identify a pool of $30 \mathrm{C}$. felis antigens using the protein microarray, but were not able protect cats from developing cytauxzoonosis through ELI.

This study further validates protein microarray as a valuable tool for high throughput antigen discovery for organisms that are unable to be cultured in vitro. Prior to this study, only a single antigenic protein (cf76), which was identified by genome synteny with related organisms, had been characterized from a genome containing over 4300 putative proteins [32]. By use of the protein microarray, we were able to rapidly discover 30 new $C$. felis antigens (Fig. 1).

In this study only a portion $(673 / 4378=15.4 \%)$ of the putative protein-encoding genes in the $C$. felis genome were analyzed. The percentage of differentially seroreactive proteins, $4.5 \%(30 / 673)$, was similar to percentages identified in other pathogens [34, 40, 64-67]. The pool of 673 proteins was chosen using methods to maximize the likelihood of identifying antigenic proteins. Studies evaluating the antigenicity of the remaining 3705 putative $C$. felis proteins should be the focus of future studies.

A limitation to this approach is that antigens identified by protein microarray are restricted to those that elicit a humoral immune response. Protection against $C$. felis is likely to require both a cell-mediated and humoral immune response, as the parasite resides intracellularly in the feline host. Unfortunately, high throughput methods for the identification of antigens that stimulate T-cells have only recently emerged, and are not costeffective or widely available, particularly for use in a feline system [35, 68-70]. It has been suggested that proteins that induce a cellular immune response are also likely to be recognized by serum antibodies [36]. Therefore the antigens identified in this study should also be assessed for T-cell reactivity.

Unfortunately, ELI using antigens identified on the protein microarray in this study did not prevent $C$. felis infection or clinical disease (cytauxzoonosis). There are a number of possible explanations why ELI failed in this study. First, it is possible that failure occurred in any number of the steps required for a DNA vaccine to effectively confer immunity. This could include plasmid delivery into cells, expression of the antigens by the host cell, presentation of peptides on MHC molecules, and adequate stimulation of both innate and adaptive immune responses [42, 71]. Alternatively, vaccination could be 
Table 4 Cats rarely seroconvert against antigens included in vaccine prior to infection with Cytauxzoon felis

\begin{tabular}{|c|c|c|c|c|c|c|c|c|}
\hline \multirow[t]{2}{*}{ Candidate } & \multirow[t]{2}{*}{ Gene/ORF } & \multicolumn{3}{|l|}{ CF-1 } & \multicolumn{4}{|c|}{ CF-Library } \\
\hline & & 331 & 623 & 638 & 77 & 308 & 339 & 835 \\
\hline 19 & contig00195:6540-8711(+) & $\mathrm{N}$ & $N$ & $\mathrm{~N}$ & $Y-65$ & $\mathrm{~N}$ & $\mathrm{~N}$ & $N$ \\
\hline 3 & contig00195:8035-8711(+) & $\mathrm{N}$ & $Y-30$ & $\mathrm{~N}$ & $Y-30$ & $\mathrm{~N}$ & $\mathrm{~N}$ & $\mathrm{~N}$ \\
\hline 1 & contig00088:95434-96586(-) & $\mathrm{N}$ & $\mathrm{N}$ & $\mathrm{N}$ & $\mathrm{N}$ & $\mathrm{N}$ & $\mathrm{N}$ & $\mathrm{N}$ \\
\hline 2 & contig00034:39570-41574(+) & $\mathrm{N}$ & $\mathrm{N}$ & $\mathrm{N}$ & $\mathrm{N}$ & $\mathrm{N}$ & $\mathrm{N}$ & $\mathrm{N}$ \\
\hline 4 & contig00109:22439-22690(+) & $\mathrm{N}$ & $Y-30$ & $\mathrm{~N}$ & $\mathrm{~N}$ & $\mathrm{~N}$ & $\mathrm{~N}$ & $\mathrm{~N}$ \\
\hline 5 & contig00259:2101-4206(-) & N & $\mathrm{N}$ & $\mathrm{N}$ & $\mathrm{N}$ & $\mathrm{N}$ & $\mathrm{N}$ & $\mathrm{N}$ \\
\hline 6 & contig00010:254-1016(+) & $\mathrm{N}$ & $\mathrm{N}$ & $\mathrm{N}$ & $\mathrm{N}$ & $\mathrm{N}$ & $\mathrm{N}$ & $\mathrm{N}$ \\
\hline 7 & contig00147:58097-59225(-) & N & N & N & $\mathrm{N}$ & N & N & N \\
\hline 9 & contig00029:68709-70041(+) & $\mathrm{N}$ & $\mathrm{N}$ & $\mathrm{N}$ & $\mathrm{N}$ & $\mathrm{N}$ & $\mathrm{N}$ & N \\
\hline 10 & contig00237:32067-33665(+) & N & N & N & $\mathrm{N}$ & $\mathrm{N}$ & $\mathrm{N}$ & N \\
\hline 11 & contig00086:6446-7270(-) & N & N & N & N & N & N & N \\
\hline 12 & contig00046:25575-26421(-) & $\mathrm{N}$ & N & $\mathrm{N}$ & $\mathrm{N}$ & $\mathrm{N}$ & $\mathrm{N}$ & N \\
\hline 13 & contig00119:20915-22637(-) & $\mathrm{N}$ & $\mathrm{N}$ & N & $\mathrm{N}$ & $\mathrm{N}$ & $\mathrm{N}$ & N \\
\hline 14 & contig00260:69016-71962(+) & N & $\mathrm{N}$ & N & $\mathrm{N}$ & $\mathrm{N}$ & $\mathrm{N}$ & $\mathrm{N}$ \\
\hline 15 & contig00052:839-1019(+) & N & N & $Y-6$ & $\mathrm{~N}$ & $\mathrm{~N}$ & $\mathrm{~N}$ & N \\
\hline 16 & contig00071:75760-77446(+) & $\mathrm{N}$ & $\mathrm{N}$ & N & $\mathrm{N}$ & $\mathrm{N}$ & $\mathrm{N}$ & $\mathrm{N}$ \\
\hline 17 & contig00006:15286-16508(+) & $\mathrm{N}$ & $\mathrm{N}$ & $\mathrm{N}$ & $\mathrm{N}$ & $\mathrm{N}$ & $\mathrm{N}$ & $\mathrm{N}$ \\
\hline 18 & contig00156:32608..32875(-) & $\mathrm{N}$ & $\mathrm{N}$ & $\mathrm{N}$ & $\mathrm{N}$ & $\mathrm{N}$ & $\mathrm{N}$ & $\mathrm{N}$ \\
\hline 20 & contig00214:29581-33385(+) & N & N & N & N & N & N & $\mathrm{N}$ \\
\hline 21 & contig00047:67240-68739(+) & N & N & $\mathrm{N}$ & N & N & N & $\mathrm{N}$ \\
\hline 22 & contig00093:7841..7964(+) & N & $\mathrm{N}$ & $\mathrm{N}$ & N & $\mathrm{N}$ & $\mathrm{N}$ & $\mathrm{N}$ \\
\hline 23 & contig00130:22711..24075(-) & $\mathrm{N}$ & $\mathrm{N}$ & $\mathrm{N}$ & $\mathrm{N}$ & $\mathrm{N}$ & $\mathrm{N}$ & $\mathrm{N}$ \\
\hline 24 & contig00137:10059-13245(-) & N & $\mathrm{N}$ & $\mathrm{N}$ & $\mathrm{N}$ & N & N & N \\
\hline 25 & contig00088:68222-69173(-) & $\mathrm{N}$ & $\mathrm{N}$ & $\mathrm{N}$ & N & N & N & N \\
\hline 26 & contig00232:10901..11056(-) & $\mathrm{N}$ & $\mathrm{N}$ & $\mathrm{N}$ & $\mathrm{N}$ & N & N & N \\
\hline 27 & contig00433:34958-36380(+) & $\mathrm{N}$ & $\mathrm{N}$ & $\mathrm{N}$ & $\mathrm{N}$ & N & N & N \\
\hline 28 & contig00147:21973-23388(+) & $\mathrm{N}$ & $\mathrm{N}$ & $\mathrm{N}$ & $\mathrm{N}$ & $\mathrm{N}$ & $\mathrm{N}$ & $\mathrm{N}$ \\
\hline 29 & contig00145:9-1059(-) & $\mathrm{N}$ & $\mathrm{N}$ & $\mathrm{N}$ & $\mathrm{N}$ & N & N & N \\
\hline 30 & contig00167:23417-24638(-) & N & N & N & N & N & N & N \\
\hline 31 & contig00063:31158-31905(-) & $Y-50$ & $Y-30$ & $Y-65$ & $Y-65$ & $Y-65$ & $Y-50$ & $Y-65$ \\
\hline 32 & contig00062:98497-98689(+) & $\mathrm{N}$ & $\mathrm{N}$ & $\mathrm{N}$ & $\mathrm{N}$ & $\mathrm{N}$ & $\mathrm{N}$ & N \\
\hline 33 & contig00079:101222-102015(+) & $\mathrm{N}$ & $\mathrm{N}$ & $\mathrm{N}$ & $\mathrm{N}$ & $\mathrm{N}$ & N & N \\
\hline
\end{tabular}

Candidates included in CF-1 are grouped at the top of the table (19 and 3). Individual cat numbers are listed below respective vaccine group. $\mathrm{Y}=\mathrm{Yes}, \mathrm{N}=\mathrm{No}$, number next to $Y$ indicates day of seroconversion

ineffective due to inadequacies in dose, delivery route, vector, composition (lack of adjuvant), or vaccination schedule. Some of these deficiencies could be identified and overcome by assessing efficacy and immunogenicity of ELI (e.g. muscle biopsy to confirm plasmid expression, identifying uniform seroconversion) prior to challenge.

Second, it is possible that the antigens included in the vaccines were unable to induce a protective immune response against $C$. felis. First, recognition of a protein by antibodies does not definitively indicate a protective B-cell response [35, 36]. Furthermore, as stated previously, even if a B-cell response is generated, humoral immunity alone may not induce protection from disease. Additionally, antibodies against some of these proteins (e.g. Candidate 31 , or elongation factor-1) may not represent a $C$. felis-specific immune response. Instead, it may represent production of cross-reactive antibodies against other pathogens (e.g. Coccidia), as it has been previously shown that serological cross-reactivity occurs between Coccidia and hemoprotozoan parasites [72, 73]. The increase in seroreactivity against these proteins (Additional file 8: Supplementary Fig. 4) could represent non-specific increases secondary to vaccination, which has previously been reported for other feline protozoan parasites [74].

We were attempting to develop a low-cost, fast-track approach for the development of a vaccine against a 
highly virulent feline pathogen that has never been isolated/cultured in vitro. Additional steps that should be taken in future studies include optimization and verification of the vaccination protocol prior to challenge, including verification of humoral immune responses by enzyme-linked immunosorbent assays or Western blotting.

One individual vaccinated with CF-Library (Cat 77) developed a comprehensive, albeit weak, serological response to vaccination, including a positive response to full length and the carboxy-terminal of cf76 (Additional file 8: Supplementary Fig. 4). Seven days post infection this cat's antibody titers against all candidates decreased, suggesting that these antibodies may have been depleted during early infection (Additional file 8: Supplementary Fig. 4). Interestingly, this cat was the only individual in the study that only required minimal supportive care and no antiprotozoal therapy (Table 3). It is unclear if this was due to partial protection afforded by vaccination or due to this individual cat's immune response.

\section{Conclusions}

In conclusion, we identified 30 new $C$. felis antigens via protein microarray. These antigens could be considered for use in development of diagnostic tests or therapeutic interventions against $C$. felis. Bedside antigen detection tests are commonly used in veterinary medicine for rapid diagnosis of virulent disease [75], and monoclonal antibodies are emerging as a therapeutic tool against diseases afflicting veterinary patients [76]. Additionally, these antigens could still be considered for use in a vaccine against $C$. felis using a different vaccine platform.

\section{Additional files}

Additional file 1: Supplementary Data Set 1 Sequences of putative Cytauxzoon felis ORFs/genes selected for printing on protein microarray.

Additional file 2: Supplementary Table 1. PCR and cloning information for vaccine candidates.

Additional file 3: Supplementary Fig. 1. Cytauxzoon felis DNA vaccination pilot study design. A total of 18 cats were divided into four groups assessed in this study: three cats vaccinated with CF-1 prior to infection (red box), four cats vaccinated with CF-Library prior to infection (blue box), eight cats that were not vaccinated prior to infection (green box), and three cats that were neither vaccinated nor infected (gray box). The eight unvaccinated, infected cats were involved in a separate study testing the efficacy of novel chemotherapeutics against cytauxzoonosis. If it became evident that vaccines or chemotherapeutics were not halting the progression of disease, cats were additionally given atovaquone and azithromycin to attempt to prevent death; these cats are noted accordingly. $A \& A=$ atovaquone and azithromycin, $4 X A B X=$ pradofloxacin, doxycycline, clindamycin, and metronidazole.

Additional file 4: Supplementary Fig. 2. Timeline of vaccination, infection, and sample collection for vaccinated cats.
Additional file 5: Supplementary Table 2. Additional clinical observations and information for individual cats.

Additional file 6: Supplementary Table 3. Summary of supportive care administered to individual cats. Cats vaccinated with CF-Library received less overall supportive care.

Additional file 7: Supplementary Fig. 3. Serological responses to $C$. felis antigens are increased during chronic infection. Serologic reactivity of antigens are depicted as a heatmap in (A). Antigens are listed in rows while grouping of individuals are denoted in columns. Average signal intensity of individual antigens against serum from acute and chronic groups are depicted in (B). The majority of antigens that had a higher average reactivity against serum from chronically infected cats $(n=50)$, but two antigens were more reactive against serum from acutely infected cats ( $n=2$, denoted with yellow boxes). These two antigens were incorporated into the CF-Library vaccine as Candidates 32-33.

Additional file 8: Supplementary Fig. 4. Serological profiles of individual vaccinated cats to candidates throughout study. Arrays containing the 32 vaccine candidates included in CF-Library and in CF-1 were probed with sera samples from individual cats. Heat map shows normalized signal intensity with red strongest, white weakest, and gray intermediate. Rows denote 32 different candidates included in vaccines listed in descending order of reactivity; candidates 19 and 3 were included in CF-1, while all listed candidates were included in CF-Library. Results are organized by individual cats (identified by number at top), and survival status of each cat is indicated as "A" (alive) or " $\mathrm{D}$ " (dead). Individual columns within each cat's array represent serum samples collected at different time points through study (labeled by the day in the study the sample was collected; refer to Supplemental Fig. 2 for timeline). There was no correlation between immunization protocol, individual reactivity, and survival for most cats, with the exception of Cat 77, who had widespread yet weak reactivity against all candidates in the CF-Library vaccine prior to infection and subsequently had milder disease and did not require supportive care or antiprotozoal therapy.

\section{Authors' contributions}

MES, HM, JLT, MKS, HO, ES, DB, AV, CH, RN, LL, AT, DD, JET, ML, MR, PF, LC, and $A B$ conceived of the study, participated in its design, and drafted, read, and approved the final manuscript. MES, HM, JLT, ES, DB, and AB performed genome analysis and selection of putative vaccine candidates. MES, HM, JLT, $A V, C H, R N$, and LL performed vaccine candidate cloning, and HM manufactured the DNA vaccines. MES, JLT, MKS, HO, JET, MR, and LC performed the sample collection from and caretaking of cats. CH, RN, LL, and PF performed the proteomic and bioinformatics analysis of the microarray data. All authors read and approved the final manuscript.

\section{Author details}

${ }^{1}$ College of Veterinary Medicine, North Carolina State University, Research Building Room 464, 1060 William Moore Drive, Raleigh, NC 27607, USA. ${ }^{2}$ College of Veterinary Medicine, University of Georgia, 501 D.W. Brooks Drive, Athens, GA 30602, USA. ${ }^{3}$ College of Veterinary Medicine, University of Missouri, 1600 East Rollins, Columbia, MO 65211, USA. ${ }^{4}$ College of Agriculture and Life Sciences, North Carolina State University, 2501 Founders Dr, Raleigh, NC 27607 USA. ${ }^{5}$ School of Medicine, University of California Irvine, 1001 Health Sciences Rd, Irvine, CA 92617, USA. ${ }^{6}$ QIMR Berghofer Medical Research Institute, 300 Herston Rd, Brisbane City, QLD 4006, Australia. ${ }^{7}$ Australian Institute of Tropical Health and Medicine, James Cook University, 1 James Cook Dr, Douglas, QLD 4814, Australia. ${ }^{8}$ Center for Veterinary Health Sciences, Oklahoma State University, 208 S McFarland St, Stillwater, OK 74078, USA.

\section{Acknowledgements}

We would like to acknowledge the clinical expertise of Talli Hogen in the care of cats, the clinical pathology aid from Erin Burton in retrieving laboratory data, and the technical service of all veterinary technicians and students at the University of Missouri who aided in care of cats.

\section{Competing interests}

The authors declare that they have no competing interests. 


\section{Availability of data and materials}

All pertinent data is included in this manuscript or as figures, tables, or additional files. Any additional datasets analyzed during the current study are available from the corresponding author on reasonable request.

\section{Consent for publication}

All authors consent to the publication of this manuscript.

\section{Ethics approval and consent to participate}

Not applicable.

\section{Funding}

This research was funded by Morris Animal Foundation (microarray development and screening) and a charitable organization which wishes to remain anonymous.

\section{Publisher's Note}

Springer Nature remains neutral with regard to jurisdictional claims in published maps and institutional affiliations.

Received: 26 September 2018 Accepted: 14 December 2018

Published online: 29 December 2018

\section{References}

1. Glenn BL, Stair EL. Cytauxzoonosis in domestic cats: report of two cases in Oklahoma, with a review and discussion of the disease. J Am Vet Med Assoc. 1984;184:822-5.

2. Hoover JP, Walker DB, Hedges JD. Cytauxzoonosis in cats: eight cases (1985-1992). J Am Vet Med Assoc. 1994;205:455-60.

3. Wagner JE. A fatal cytauxzoonosis-like disease in cats. J Am Vet Med Assoc. 1976;168:585-8.

4. Ferris DH. A progress report on the status of a new disease of American cats: cytauxzoonosis. Comp Immunol Microbiol Infect Dis. 1979;1:269-76.

5. Birkenheuer AJ, Le JA, Valenzisi AM, Tucker MD, Levy MG, Breitschwerdt EB. Cytauxzoon felis infection in cats in the mid-Atlantic states: 34 cases (1998-2004). J Am Vet Med Assoc. 2006;228:568-71.

6. Jackson CB, Fisher T. Fatal cytauxzoonosis in a Kentucky cat (Felis domestiCUS). Vet Parasitol. 2006;139:192-5.

7. Andre MR, Adania CH, Machado RZ, Allegretti SM, Felippe PA, Silva KF, Nakaghi AC, Dagnone AS. Molecular detection of Cytauxzoon spp. in asymptomatic Brazilian wild captive felids. J Wildl Dis. 2009;45:234-7.

8. MacNeill AL, Barger AM, Skowronski MC, Lanka S, Maddox CW: Identification of Cytauxzoon felis infection in domestic cats from southern Illinois. J Feline Med Surg 2015

9. Carli E, Trotta M, Chinelli R, Drigo M, Sinigoi L, Tosolini P, Furlanello T, Millotti A, Caldin M, Solano-Gallego L. Cytauxzoon sp. infection in the first endemic focus described in domestic cats in Europe. Vet Parasitol. 2012;183:343-52.

10. Alho AM, Silva J, Fonseca MJ, Santos F, Nunes C, de Carvalho LM, Rodrigues M, Cardoso L. First report of Cytauxzoon sp. infection in a domestic cat from Portugal. Parasit Vectors. 2016;9:220.

11. Legroux JP, Halos L, Rene-Martellet M, Servonnet M, Pingret JL, Bourdoiseau G, Baneth G, Chabanne L. First clinical case report of Cytauxzoon sp. infection in a domestic cat in France. BMC Vet Res. 2017;13:81.

12. Diaz-Reganon D, Villaescusa A, Ayllon T, Rodriguez-Franco F, Baneth G Calleja-Bueno L, Garcia-Sancho M, Agulla B, Sainz A. Molecular detection of Hepatozoon spp. and Cytauxzoon sp. in domestic and stray cats from Madrid, Spain. Parasit Vectors. 2017;10:112

13. Nentwig A, Meli ML, Schrack J, Reichler IM, Riond B, Gloor C, Howard J, Hofmann-Lehmann R, Willi B. First report of Cytauxzoon sp. infection in domestic cats in Switzerland: natural and transfusion-transmitted infections. Parasit Vectors. 2018;11:292.

14. Glenn BL, Kocan AA, Blouin EF. Cytauxzoonosis in bobcats. J Am Vet Med Assoc. 1983;183:1155-8

15. Haber MD, Tucker MD, Marr HS, Levy JK, Burgess J, Lappin MR, Birkenheuer AJ. The detection of Cytauxzoon felis in apparently healthy freeroaming cats in the USA. Vet Parasitol. 2007;146:316-20.
16. Walker DB, Cowell RL. Survival of a domestic cat with naturally acquired cytauxzoonosis. J Am Vet Med Assoc. 1995;206:1363-5.

17. Rizzi TE, Reichard MV, Cohn LA, Birkenheuer AJ, Taylor JD, Meinkoth JH. Prevalence of Cytauxzoon felis infection in healthy cats from enzootic areas in Arkansas, Missouri, and Oklahoma. Parasit Vectors. 2015:8:13.

18. Meinkoth J, Kocan AA, Whitworth L, Murphy G, Fox JC, Woods JP. Cats surviving natural infection with Cytauxzoon felis: 18 cases (1997-1998). J Vet Intern Med. 2000;14:521-5.

19. Brown HM, Lockhart JM, Latimer KS, Peterson DS. Identification and genetic characterization of Cytauxzoon felis in asymptomatic domestic cats and bobcats. Vet Parasitol. 2010;172:311-6.

20. Cohn LA, Birkenheuer AJ, Brunker JD, Ratcliff ER, Craig AW. Efficacy of atovaquone and azithromycin or imidocarb dipropionate in cats with acute cytauxzoonosis. J Vet Intern Med. 2011;25:55-60.

21. Raghavan RK, Almes K, Goodin DG, Harrington JA Jr, Stackhouse PW Jr. Spatially heterogeneous land cover/land use and climatic risk factors of tick-borne feline cytauxzoonosis. Vector Borne Zoonotic Dis. 2014;14:486-95.

22. Cohn LA, Birkenheuer AJ. Cytauxzoonosis. In: Greene CE, editor. Infectious diseases of the dog and cat. 4th ed. Philadelphia: W.B. Saunders; 2012. p. xxi.

23. Birkenheuer AJ, Marr HS, Warren C, Acton AE, Mucker EM, Humphreys JG, Tucker MD. Cytauxzoon felis infections are present in bobcats (Lynx rufus) in a region where cytauxzoonosis is not recognized in domestic cats. Vet Parasitol. 2008;153:126-30.

24. Shock BC, Birkenheuer AJ, Patton LL, Olfenbuttel C, Beringer J, Grove DM, Peek M, Butfiloski JW, Hughes DW, Lockhart JM, et al. Variation in the ITS-1 and ITS-2 rRNA genomic regions of Cytauxzoon felis from bobcats and pumas in the eastern United States and comparison with sequences from domestic cats. Vet Parasitol. 2012;190:29-35.

25. Reichard MV, Thomas JE, Arther RG, Hostetler JA, Raetzel KL, Meinkoth $\mathrm{JH}$, Little SE. Efficacy of an imidacloprid 10\%/flumethrin 4.5\% collar (Seresto(R), Bayer) for preventing the transmission of Cytauxzoon felis to domestic cats by Amblyomma americanum. Parasitol Res. 2012;112(Suppl 1):11-20.

26. Salo AL, Stone E: A survey of the views of US veterinary teaching faculty to owned cat housing practices. J Feline Med Surg 2014.

27. Loyd KA, Hernandez SM, Abernathy KJ, Shock BC, Marshall GJ. Risk behaviours exhibited by free-roaming cats in a suburban US town. Vet Rec. 2013;173:295

28. Gates MC, Nolan TJ. Factors influencing heartworm, flea, and tick preventative use in patients presenting to a veterinary teaching hospital. Prev Vet Med. 2010;93:193-200.

29. Motzel SL, Wagner JE. Treatment of experimentally induced cytauxzoonosis in cats with parvaquone and buparvaquone. Vet Parasitol. 1990:35:131-8

30. Shindel N, Dardiri AH, Ferris DH. An indirect fluorescent antibody test for the detection of Cytauxzoon-like organisms in experimentally infected cats. Can J Comp Med. 1978;42:460-5.

31. Uilenberg G, Franssen FF, Perie NM. Relationships between Cytauxzoon felis and African piroplasmids. Vet Parasitol. 1987;26:21-8.

32. Tarigo JL, Scholl EH, Bird DM, Brown CC, Cohn LA, Dean GA, Levy MG, Doolan DL, Trieu A, Nordone SK, et al. A novel candidate vaccine for cytauxzoonosis inferred from comparative apicomplexan genomics. PLoS ONE. 2013;8:e71233.

33. Rappuoli R. Reverse vaccinology, a genome-based approach to vaccine development. Vaccine. 2001;19:2688-91.

34. Liang L, Doskaya M, Juarez S, Caner A, Jasinskas A, Tan X, Hajagos BE, Bradley PJ, Korkmaz M, Guruz Y, et al. Identification of potential serodiagnostic and subunit vaccine antigens by antibody profiling of toxoplasmosis cases in Turkey. Mol Cell Proteomics. 2011;10(M110):006916.

35. Davies DH, Duffy P, Bodmer JL, Felgner PL, Doolan DL. Large screen approaches to identify novel malaria vaccine candidates. Vaccine. 2015:33:7496-505.

36. Doolan DL, Mu Y, Unal B, Sundaresh S, Hirst S, Valdez C, Randall A, Molina $D$, Liang $X$, Freilich DA, et al. Profiling humoral immune responses to $P$. falciparum infection with protein microarrays. Proteomics. 2008;8:4680-94.

37. Driguez P, Doolan DL, Loukas A, Felgner PL, McManus DP. Schistosomiasis vaccine discovery using immunomics. Parasit Vectors. 2010;3:4. 
38. Driguez P, Doolan DL, Molina DM, Loukas A, Trieu A, Felgner PL, McManus DP. Protein microarrays for parasite antigen discovery. Methods Mol Biol. 2015;1201:221-33.

39. Zhou X, Huang JL, Shen HM, Xu B, Chen JH, Zhou XN: Immunomics analysis of Babesia microti protein markers by high-throughput screening assay. Ticks Tick Borne Dis 2018.

40. Lessa-Aquino C, Borges Rodrigues C, Pablo J, Sasaki R, Jasinskas A, Liang L, Wunder EA Jr, Ribeiro GS, Vigil A, Galler R, et al. Identification of seroreactive proteins of Leptospira interrogans serovar copenhageni using a highdensity protein microarray approach. PLoS Negl Trop Dis. 2013;7:e2499.

41. Lessa-Aquino C, Lindow JC, Randall A, Wunder E, Pablo J, Nakajima R, Jasinskas A, Cruz JS, Damiao AO, Nery N, et al. Distinct antibody responses of patients with mild and severe leptospirosis determined by whole proteome microarray analysis. PLoS Negl Trop Dis. 2017;11:e0005349.

42. Smooker PM, Rainczuk A, Kennedy N, Spithill TW. DNA vaccines and their application against parasites-promise, limitations and potential solutions. Biotechnol Annu Rev. 2004;10:189-236.

43. Talaat AM, Stemke-Hale K. Expression library immunization: a road map for discovery of vaccines against infectious diseases. Infect Immun. 2005;73:7089-98.

44. Barry MA, Howell DP, Andersson HA, Chen JL, Singh RA. Expression library immunization to discover and improve vaccine antigens. Immunol Rev. 2004;199:68-83.

45. Smooker PM, Setiady YY, Rainczuk A, Spithill TW. Expression library immunization protects mice against a challenge with virulent rodent malaria. Vaccine. 2000;18:2533-40.

46. Shibui A, Nakae S, Watanabe J, Sato Y, Tolba ME, Doi J, Shiibashi T, Nogami S, Sugano S, Hozumi N. Screening of novel malaria DNA vaccine candidates using full-length cDNA library. Exp Parasitol. 2013;135:546-50.

47. Alberti E, Acosta A, Sarmiento ME, Hidalgo C, Vidal T, Fachado A, Fonte L, Izquierdo L, Infante JF, Finlay CM, Sierra G. Specific cellular and humoral immune response in Balb/c mice immunised with an expression genomic library of Trypanosoma cruzi. Vaccine. 1998;16:608-12.

48. Piedrafita D, Xu D, Hunter D, Harrison RA, Liew FY. Protective immune responses induced by vaccination with an expression genomic library of Leishmania major. J Immunol. 1999;163:1467-72.

49. Melby PC, Ogden GB, Flores HA, Zhao W, Geldmacher C, Biediger NM, Ahuja SK, Uranga J, Melendez M. Identification of vaccine candidates for experimental visceral leishmaniasis by immunization with sequential fractions of a cDNA expression library. Infect Immun. 2000;68:5595-602.

50. Davies DH, Liang X, Hernandez JE, Randall A, Hirst S, Mu Y, Romero KM, Nguyen TT, Kalantari-Dehaghi M, Crotty S, et al. Profiling the humoral immune response to infection by using proteome microarrays: highthroughput vaccine and diagnostic antigen discovery. Proc Natl Acad Sci USA. 2005;102:547-52.

51. Pamelard F, Even G, Apostol C, Preda C, Dhaenens C, Fafeur V, Desmet R, Melnyk O. PASE: a web-based platform for peptide/protein microarray experiments. Methods Mol Biol. 2009:570:413-30.

52. Taylor CF, Paton NW, Lilley KS, Binz PA, Julian RK Jr, Jones AR, Zhu W, Apweiler R, Aebersold R, Deutsch EW, et al. The minimum information about a proteomics experiment (MIAPE). Nat Biotechnol. 2007:25:887-93.

53. Felgner PL, Kayala MA, Vigil A, Burk C, Nakajima-Sasaki R, Pablo J, Molina DM, Hirst S, Chew JS, Wang D, et al. A Burkholderia pseudomallei protein microarray reveals serodiagnostic and cross-reactive antigens. Proc Natl Acad Sci USA. 2009;106:13499-504.

54. Kreil DP, Karp NA, Lilley KS. DNA microarray normalization methods can remove bias from differential protein expression analysis of 2D difference gel electrophoresis results. Bioinformatics. 2004;20:2026-34.

55. Sundaresh S, Randall A, Unal B, Petersen JM, Belisle JT, Hartley MG, Duffield M, Titball RW, Davies DH, Felgner PL, Baldi P. From protein microarrays to diagnostic antigen discovery: a study of the pathogen Francisella tularensis. Bioinformatics. 2007;23:1508-18.

56. Sundaresh S, Doolan DL, Hirst S, Mu Y, Unal B, Davies DH, Felgner PL, Baldi P. Identification of humoral immune responses in protein microarrays using DNA microarray data analysis techniques. Bioinformatics. 2006:22:1760-6.

57. Baldi P, Long AD. A Bayesian framework for the analysis of microarray expression data: regularized $t$-test and statistical inferences of gene changes. Bioinformatics. 2001;17:509-19.
58. Long AD, Mangalam HJ, Chan BY, Tolleri L, Hatfield GW, Baldi P. Improved statistical inference from DNA microarray data using analysis of variance and a Bayesian statistical framework. Analysis of global gene expression in Escherichia coli K12. J Biol Chem. 2001;276:19937-44.

59. Hochberg Y, Benjamini Y. More powerful procedures for multiple significance testing. Stat Med. 1990;9:811-8.

60. Bondy PJ Jr, Cohn LA, Tyler JW, Marsh AE. Polymerase chain reaction detection of Cytauxzoon felis from field-collected ticks and sequence analysis of the small subunit and internal transcribed spacer 1 region of the ribosomal RNA gene. J Parasitol. 2005;91:458-61.

61. Birkenheuer AJ, Marr H, Alleman AR, Levy MG, Breitschwerdt EB. Development and evaluation of a PCR assay for the detection of Cytauxzoon felis DNA in feline blood samples. Vet Parasitol. 2006;137:144-9.

62. Reichard MV, Edwards AC, Meinkoth JH, Snider TA, Meinkoth KR, Heinz RE, Little SE. Confirmation of Amblyomma americanum (Acari: Ixodidae) as a vector for Cytauxzoon felis (Piroplasmorida: Theileriidae) to domestic cats. J Med Entomol. 2010;47:890-6.

63. Freeman $\mathrm{GH}$, Halton JH. Note on an exact treatment of contingency, goodness of fit and other problems of significance. Biometrika. 1951;38:141-9.

64. Vigil A, Ortega R, Jain A, Nakajima-Sasaki R, Tan X, Chomel BB, Kasten RW, Koehler JE, Felgner PL. Identification of the feline humoral immune response to Bartonella henselae infection by protein microarray. PLoS ONE. 2010;5:e11447.

65. Nakajima R, Escudero R, Molina DM, Rodriguez-Vargas M, Randall A, Jasinskas A, Pablo J, Felgner PL, AuCoin DP, Anda P, Davies DH. Towards development of improved serodiagnostics for tularemia by use of Francisella tularensis proteome microarrays. J Clin Microbiol. 2016;54:1755-65.

66. Chuquiyauri R, Molina DM, Moss EL, Wang R, Gardner MJ, Brouwer KC, Torres S, Gilman RH, Llanos-Cuentas A, Neafsey DE, et al. Genome-scale protein microarray comparison of human antibody responses in plasmodium vivax relapse and reinfection. Am J Trop Med Hyg. 2015;93:801-9.

67. Driguez P, Li Y, Gaze S, Pearson MS, Nakajima R, Trieu A, Doolan DL, Felgner PL, Hou X, Cardoso FC, et al. Antibody signatures reflect different disease pathologies in patients with Schistosomiasis due to Schistosoma japonicum. J Infect Dis. 2016;213:122-30.

68. Cardoso FC, Roddick JS, Groves P, Doolan DL. Evaluation of approaches to identify the targets of cellular immunity on a proteome-wide scale. PLoS ONE. 2011;6:e27666.

69. Picard MD, Cohane KP, Gierahn TM, Higgins DE, Flechtner JB. Highthroughput proteomic screening identifies Chlamydia trachomatis antigens that are capable of eliciting $T$ cell and antibody responses that provide protection against vaginal challenge. Vaccine. 2012;30:4387-93.

70. Grubaugh D, Flechtner JB, Higgins DE. Proteins as T cell antigens: methods for high-throughput identification. Vaccine. 2013;31:3805-10.

71. Williams JA, Carnes AE, Hodgson CP. Plasmid DNA vaccine vector design: impact on efficacy, safety and upstream production. Biotechnol Adv. 2009;27:353-70.

72. Gabrielsen AA Jr, Jensen JB, Boland MT. Identification and partial characterization of exoantigens derived from medium used to culture Plasmodium falciparum. Am J Trop Med Hyg. 1983;32:671-4.

73. Herzenberg AM, Barta JR, Desser SS. Monoclonal antibodies raised against coccidia and malarial parasites recognize antigenic epitopes found in lankesterellid and adeleorin parasites. J Parasitol. 1995;81:543-8.

74. Lappin MR, Chavkin MJ, Munana KR, Cooper CM. Feline ocular and cerebrospinal fluid Toxoplasma gondii-specific humoral immune responses following specific and nonspecific immune stimulation. Vet Immunol Immunopathol. 1996;55:23-31.

75. Kantere MC, Athanasiou LV, Spyrou V, Kyriakis CS, Kontos V, Chatzopoulos DC, Tsokana CN, Billinis C. Diagnostic performance of a rapid in-clinic test for the detection of Canine Parvovirus under different storage conditions and vaccination status. J Virol Methods. 2015;215-216:52-5.

76. Michels GM, Ramsey DS, Walsh KF, Martinon OM, Mahabir SP, Hoevers JD, Walters RR, Dunham SA. A blinded, randomized, placebo-controlled, dose determination trial of lokivetmab (ZTS-00103289), a caninized, anti-canine IL-31 monoclonal antibody in client owned dogs with atopic dermatitis. Vet Dermatol. 2016;27:478-e129. 